\title{
R23 - CONSTRUÇÃO DE UM VETOR PARA RECOMBINAÇÃO DE INTEGRASES DO HIV-1
}

\author{
Bianca Duarte $^{1}$, Michelli de Oliveira $^{1}$, Bernard Piñeiro ${ }^{1}$, Amilcar Tanuri $^{1}$
}

1. Universidade Federal do Rio de Janeiro/Laboratório de Virologia Molecular Aplicada

Objetivo: Este trabalho visou desenvolver uma ferramenta molecular para a produção de HIV-1 recombinantes de Integrase através da construção de um vetor plasmidial contendo o genoma completo do vírus, para recombinação com Integrases (INs) geneticamente diversas de vírus circulantes na população. $\mathrm{O}$ vetor recombinante gerado permite o desenvolvimento de ensaio fenotípico clínico de Integrases de pacientes para análise de vírus susceptíveis/resistentes aos Inibidores de Integrase, como o atualmente utilizado para terapia de resgate - Raltegravir (FDA, 2007), uma vez que a análise fenotípica do padrão de resistência clínica frente à diversidade genética das Integrases (INs) demonstra possuir impacto clínico no tratamento de pacientes em falha terapêutica aos medicamentos de primeira linha.

Métodos: O vetor pNL4-3Luc foi utilizado por possuir o genoma completo do HIV-1 e conter o gene repórter de luciferase no lugar do gene nef. Foi realizada a deleção do gene de Integrase, gerando o vetor recombinação de Integrases, pNL4-3LucAInt. Para estudar a capacidade de produção de vírus integrase recombinantes, realizou-se dois ensaios de transfecção em células 293-T. No primeiro ensaio utilizou-se o vetor pNL4-3Luc $\Delta$ Int linear e co-transfectou-se com amplicons do gene de integrase subtipo B ou C. No segundo ensaio de transfecção foi realizada recombinação homóloga in vitro (GIBSON, 2009) e estes vetores integrase específicos foram transfectados. Além disso, foi realizada a extração de RNA de vírus subtipos B, C e F susceptíveis e resistentes aos inibidores de Integrase em cultura para realização de RT-PCR. Os amplicons de Integrases gerados foram recombinados com o vetor pNL4-3Luc $\Delta$ Int linear por recombinação homóloga in vitro.

Resultados: Os vírus integrase recombinantes gerados, puderam ser avaliados quanto à eficiência de infecção após leitura de luminescência pós infecção em células MT-4 susceptíveis. Apenas o segundo ensaio foi capaz de produzir vírus recombinantes de 
Integrase infecciosos, gerando o equivalente à $10^{6}$ Sinais de Luz para os vírus recombinantes com Integrase do subtipo C e $10^{5}$ Sinais de Luz para os do subtipo B. Diante da eficiente infecção pelos vírus recombinantes do segundo ensaio, foram realizadas reações de recombinação homóloga in vitro utilizando amplicons de Integrase de vírus susceptíveis e resistentes aos INIs subtipos B, C e F produzidos em cultura. Como resultado, obteve-se uma eficiência de produção de vetores corretamente recombinados de mínimo $15 \%$ e máximo de $85 \%$ com o uso da técnica.

\section{Conclusões:}

Diante do exposto, a observação da alta emissão de luz de células infectadas por vírus integrase recombinantes com gene repórter luciferase pode ser um método eficiente para avaliar a susceptibilidade destes vírus em presença de inibidores. Portanto, a recombinação homóloga in vitro demonstrou-se eficiente para a produção de vetores Integrase recombinantes com o objetivo de serem utilizados para produção viral em testes fenotípicos frente aos INIs. 